\title{
ARTIFICIAL ORGANS 2000 ESAO
}

Satellite Symposium on the Occasion of the 25th Anniversary of the Department of Nephrology of the Ss. Cyril and Methodius University, Skopje, R. Macedonia, November 25-26, 2000

\section{Momir H. Polenakovic}

Macedonian Academy of Sciences and Arts, North Macedonia

Corresponding author: Momir H. Polenakovic, Macedonian Academy of Sciences and Arts, Blvd. Krste Misirkov 2, Skopje, N. Macedonia, e-mail: momir@manu.edu.mk

\section{ABSTRACT}

Artificial Organs 2000 Satellite Symposium of European Society for Artificial Organs (ESAO) was organized by the Macedonian Society for Nephrology, Dialysis, Transplantation and Artificial Organs (MSNDTAO) and the Macedonian Academy of Sciences and Arts (MASA) on November 25-26, 2000 on the occasion of the 25th Anniversary of the Department of Nephrology of the Ss. Cyril and Methodius University, Skopje, R. Macedonia.

The main topics of this symposium were: Blood-purification techniques, Artificial Kidney, Metabolic- and Cardiac-Assist Systems as well as Biomaterials to be used for Artificial Organs.

H. Klinkmann (Glasgow, United Kingdom), D. Falkenhagen (Krems, Austria), U. Baurmeister (Wuppertal, Germany), V. Bonomini, S. Stefoni (Bologna, Italy), R. Vanholder (Ghent, Belgium), S. Stiller (Aachen, Germany), H. Mann, H. Melzer (Aachen, Germany), J. Pop-Jordanov, N. Pop-Jordanova (Skopje, R. Macedonia), B. Stegmayr (Umea, Sweden), M. Mydlik, K. Derzisova, O. Racz, A. Sipulova, J. Boldizsar, E. Lovasova, M. Hribikova (Kosice, Slovak Republic), A. Jörres (Berlin, Germany), M. Polenakovic (Skopje, R. Macedonia), J. Vienken (Bad Homburg, Germany), S. Bowry (Bad Homburg, Germany), E. Piskin (Ankara, Turkey), J. Klinkmann, W. Schimmelpfennig, H. Lantow, W. Rigger. (Teterow, Germany), A. Sikole (Skopje, R. Macedonia), A. Oncevski, P. Dejanov, V. Gerasimovska, M. Polenakovic (Skopje, R. Macedonia), J. Wojcicki (Warsaw, Poland), K. Affeld (Berlin, Germany), G. Rakhorst et al. (Groningen, The Netherlands), Z. Mitrev (Skopje, R. Macedonia), S. Kedev, G. Guagliumi, O. Valsecchi, M. Tespili (Skopje, R. Macedonia, Bergamo, Italy) have presented their papers at the Symposium. The presentations provoked a fruitful discussion and it was concluded that they should be published.

The papers were published in the International Journal of Artificial Organs of the European Society for Artificial Organs (ESAO) as a special issue on "Artificial Organs 2000 ESAO Satellite Symposium Skopje, R. Macedonia", Guest Editors: M. H. Polenakovic, Skopje and J. Vienken, Bad Homburg; Vol. 25, No. 5, 2002.

Keywords: Artificial Kidney, Blood Purification, Vascular Access, Cardiac Assist Technology, Metabolic Assist, Tissue Engineering, Psychophysiology 

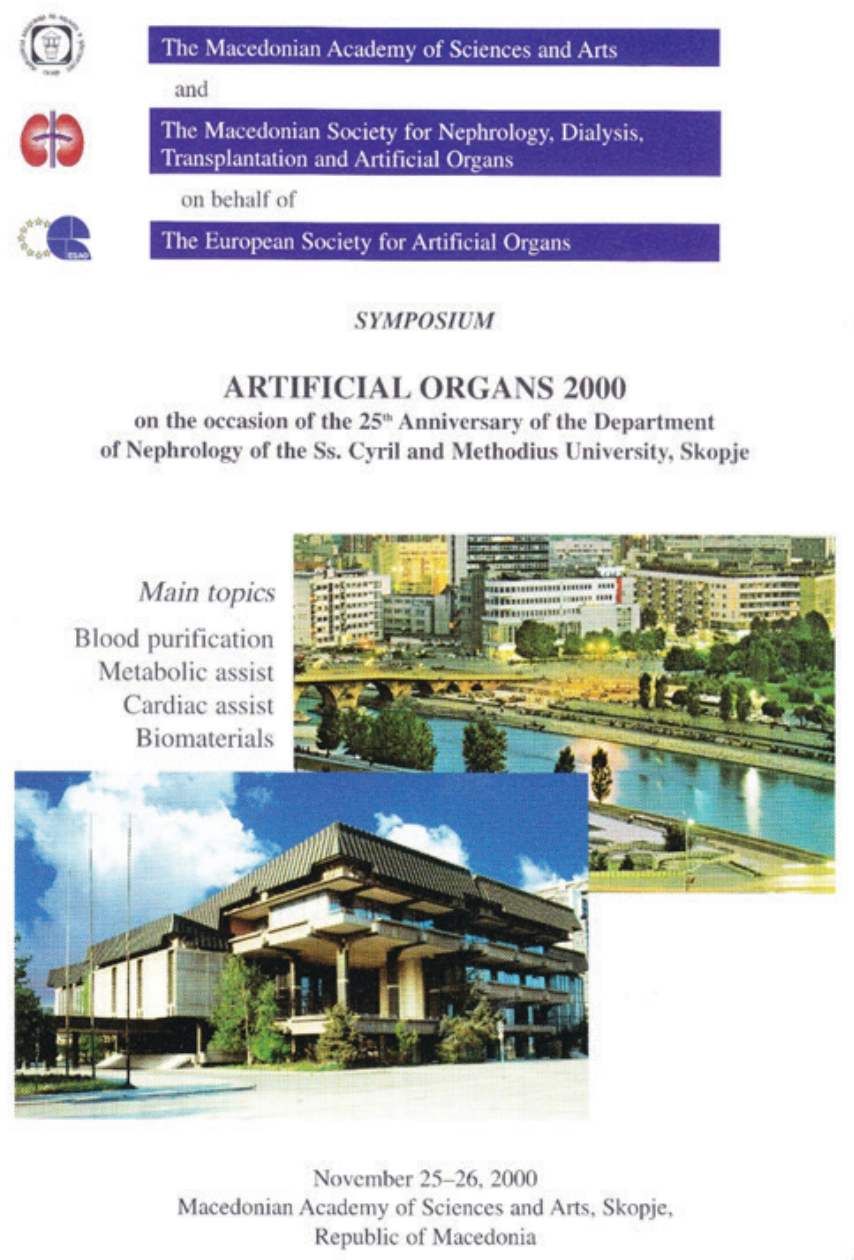

Fig. 1. Program of the Symposium

In 1943 W. Kolff created the first artificial organ - the "artificial kidney", which partially replaced the function of the natural kidney (1).

The first hemodialysis in R. Macedonia was performed in May 1961 according to the writing of Prof. T. Stojcevski, at the Transfusion Institute of R. Macedonia, by Dr. Berisav Vujasin (2).

The hemodialysis was performed with a KolffBrigham rotating drum artificial kidney. The patient was anuric after a suicidal poisoning. Despite the several hemodialyses, the patient died.

This first artificial kidney is kept at the Institute of Nephrology in Struga.

In 1965 we have obtained a new artificial kidney "Websinger" with a sigma motor pump, with possibilities for use of disposable Kolff "twin coil" dialyzer (3). Between 1959 and 1971 hemodialysis (HD) was performed only in patients with acute re- nal failure on the Renal Unit at the Department of Medicine, Medical Faculty in Skopje (3).

In May 1971, a Unit for Chronic HD was founded at the Renal Unit and the program of maintenance hemodialysis (MHD) was started with five Stuttgart Fresenius machines and 12 patients dialyzed on twin coil dialyzers. That was a great incentive for the development of HD in the Republic of Macedonia enforced by the great number of patients with end stage renal disease (4).

The health workers at the Nephrology Clinic were the driving force in the development of HD and, thus, the application of artificial organs (kidney) in medicine. It were almost 25 years since the establishment of the Nephrology Clinic.

The members of the European Society for Artificial Organs (ESAO) proposed to organize a satellite symposium of ESAO on artificial organs - Artificial Organs 2000 in Skopje, on the occasion of 25 years 
since the establishment of the Clinic for Nephrology. It was considered that such a symposium will positively affect the development and application of artificial organs in R. Macedonia and beyond. It was agreed that the symposium would be organized by the Macedonian Society for Nephrology, Dialysis, Transplantation and Artificial Organs (MSNDTAO) and the Macedonian Academy of Sciences and Arts (MASA) on behalf of ESAO, on November 25-26, 2000 at the MASA premises in Skopje.

The symposium was opened with the welcoming addresses by: G. Efremov, President of the Macedonian Academy of Sciences and Arts, D. Falkenhagen, President of the European Society for Artficial Organs (ESAO) and H. Klinkmann, Dean of the International Faculty for Artificial Organs (INFA). The Opening Speech was delivered by M. Polenakovic, President of the Organizing Committee.

Prominent scientists from abroad and from the Republic of Macedonia gave presentations at the symposium:

H. Klinkmann (Glasgow, United Kingdom): Blood purification in clinical medicine by apheresis and adsorption technologies; D. Falkenhagen (Krems, Austria): New developments and artificial liver support; U. Baurmeister (Wuppertal, Germany): Adsorptive porous system (APoS) for the treatment of whole blood plasma; V. Bonomini, S. Stefoni (Bologna, Italy): Priority choices in renal replacement therapy; R. Vanholder (Ghent, Belgium): Vascular access: future directions to follow; S. Stiller (Aachen, Germany): Kt/Vß-2m new parameters of dialysis adequacy?; H. Mann, H. Melzer (Aachen, Germany): Testing protein permeability of dialysis membranes using SDS-PAGE; J. Pop-Jordanov, N. Pop-Jordanova (Skopje, R. Macedonia): Psychophysiological comorbidity and computerized biofeedback; B. Stegmayr (Umea, Sweden): Various clinical approaches to minimize complications in peritoneal dialysis; M. Mydlik, K. Derzisova, O. Racz, A. Sipulova, J. Boldizsar, E. Lovasova, M. Hribikova (Kosice, Slovak Republic): Vitamin E as an antioxidant agent in CAPD patients; A. Jörres (Berlin, Germany): Extracorporeal treatment strategy in acute renal failure; M. Polenakovic (Skopje, R. Macedonia): Dialysis and PF therapy in 2000 in R. Macedonia; J. Vienken (Bad Homburg, Germany): Polymers in nephrology; S. Bowry (Bad Homburg, Germany): Dialysis membranes of today; E. Piskin (Ankara, Turkey): Biodegradable polymeric matrices for bioartificial organs; J. Klinkmann, W. Schimmelpfennig, H. Lantow, W. Rigger. (Teterow, Germany): LIFE 18 a new technical solution for an integrated apheresis machine; A. Sikole (Skopje, R. Macedonia): The impact of anarmia on heart morphology in chronic renal failure; A. Oncevski, P. Dejanov, V. Gerasimovska, M. Polenakovic (Skopje, R. Macedonia): Approach to vascular access for hemodialysis experience from R. Macedonia; J. Wojcicki (Warsaw, Poland): Intensive diabetes treatment new trends in technical support; K. Affeld (Berlin, Germany): Problems and challenges of permanently implanted cardiac assist system; G. Rakhorst et al. (Groningen, The Netherlands): Animal models for cardiac assist research; Z. Mitrev (Skopje, R.

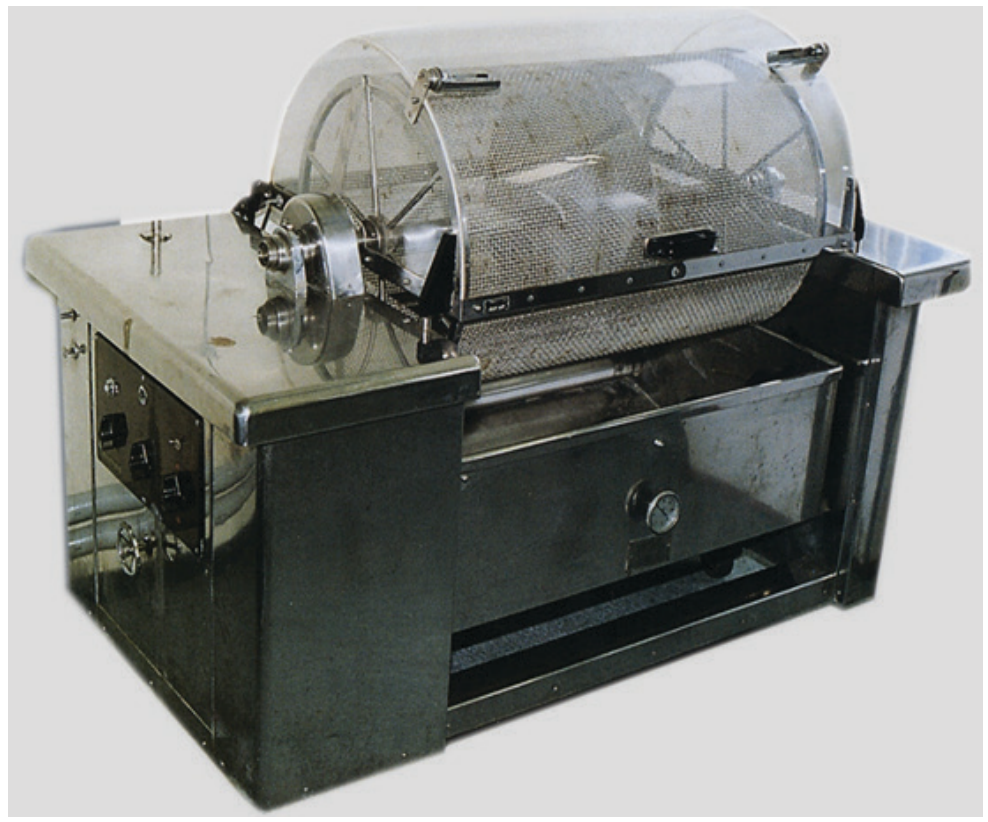

Fig. 2. Kolff-Brigham Rotating Drum Artificial Kidney 
Macedonia): Transplantation or alternative surgical therapy in patients with ischemic dilatative cardiomyopathy and aneurysmatic augmentation of the left ventricular cavity; S. Kedev, G. Guagliumi, O.
Valsecchi, M. Tespili (Skopje, R. Macedonia, Bergamo, Italy): Heparin-coated stents in acute coronary syndromes: a randomized comparison with uncoated stents in unselected native coronary lesions.

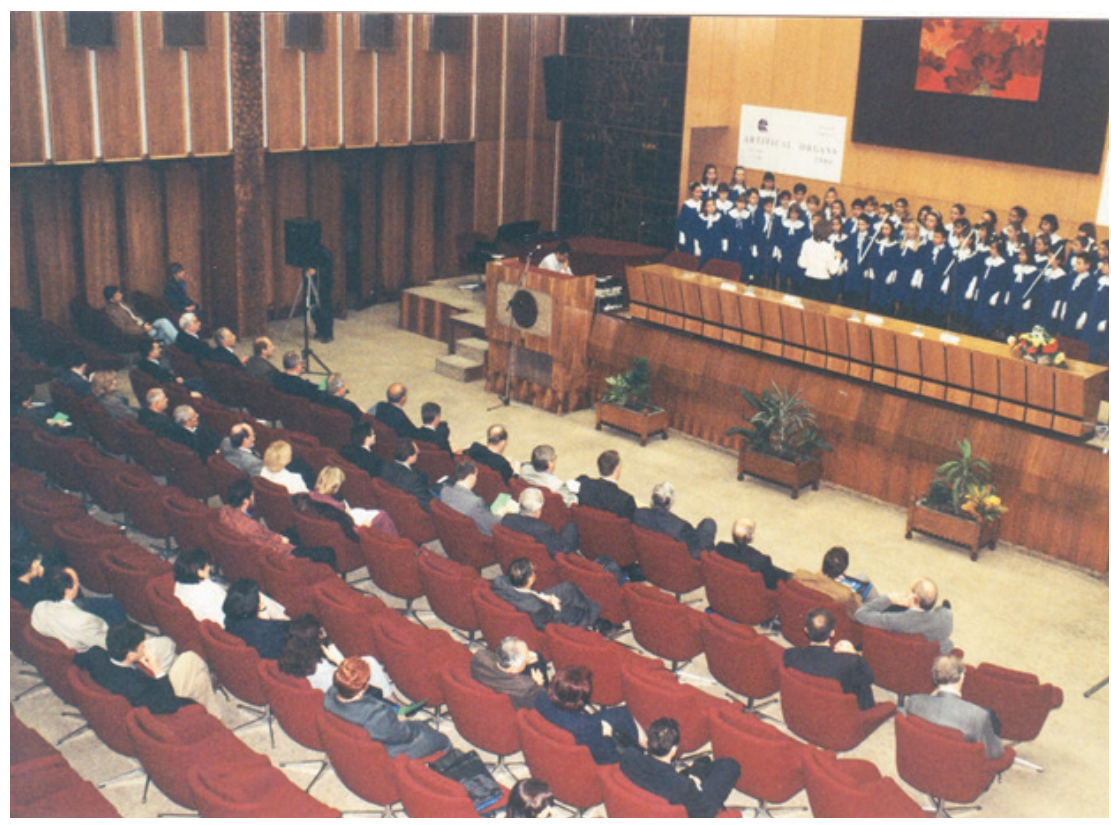

Fig. 3. Opening of the Artificial Organs 2000 ESAO Satellite Symposium

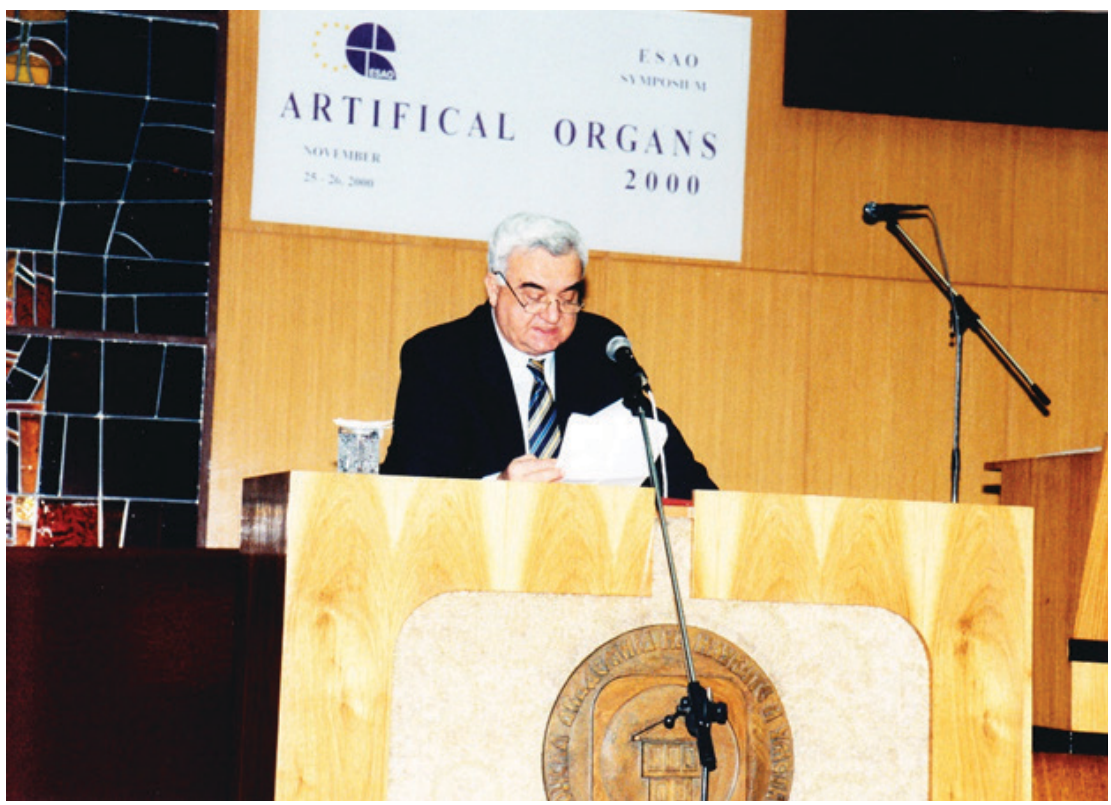

Fig. 4. M. Polenakovic - Opening of the Artificial Organs 2000 ESAO Satellite Symposium 


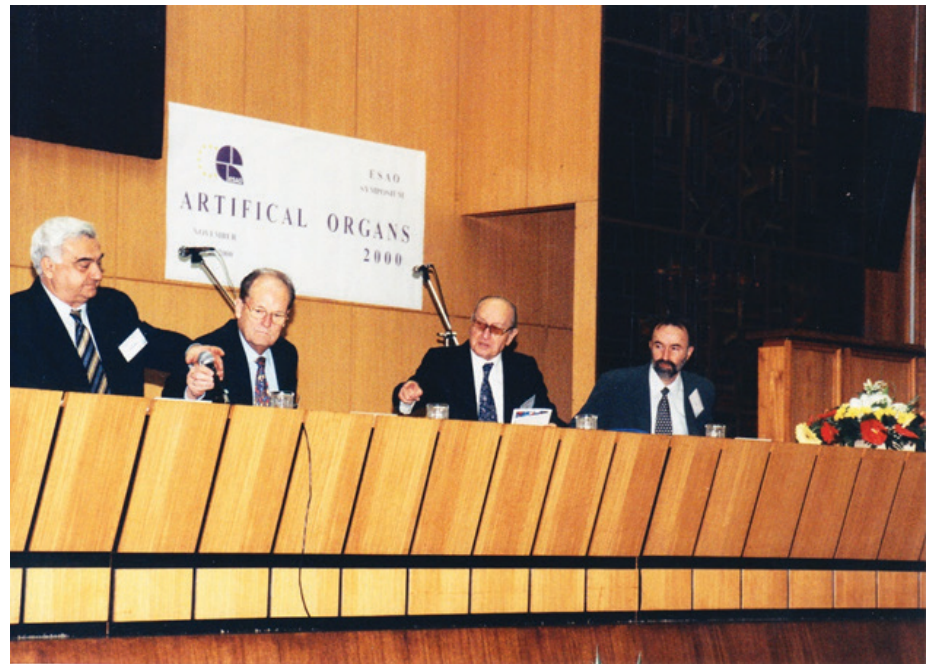

Fig. 5. From left to right: $M$. Polenakovic, H. Klinkmann, I. Tadzer and A. Sikole

Fig. 6. From left to right: $K$. Affeld, M. Polenakovic, J. Vienken, G. Efremov and H. Klinkmann
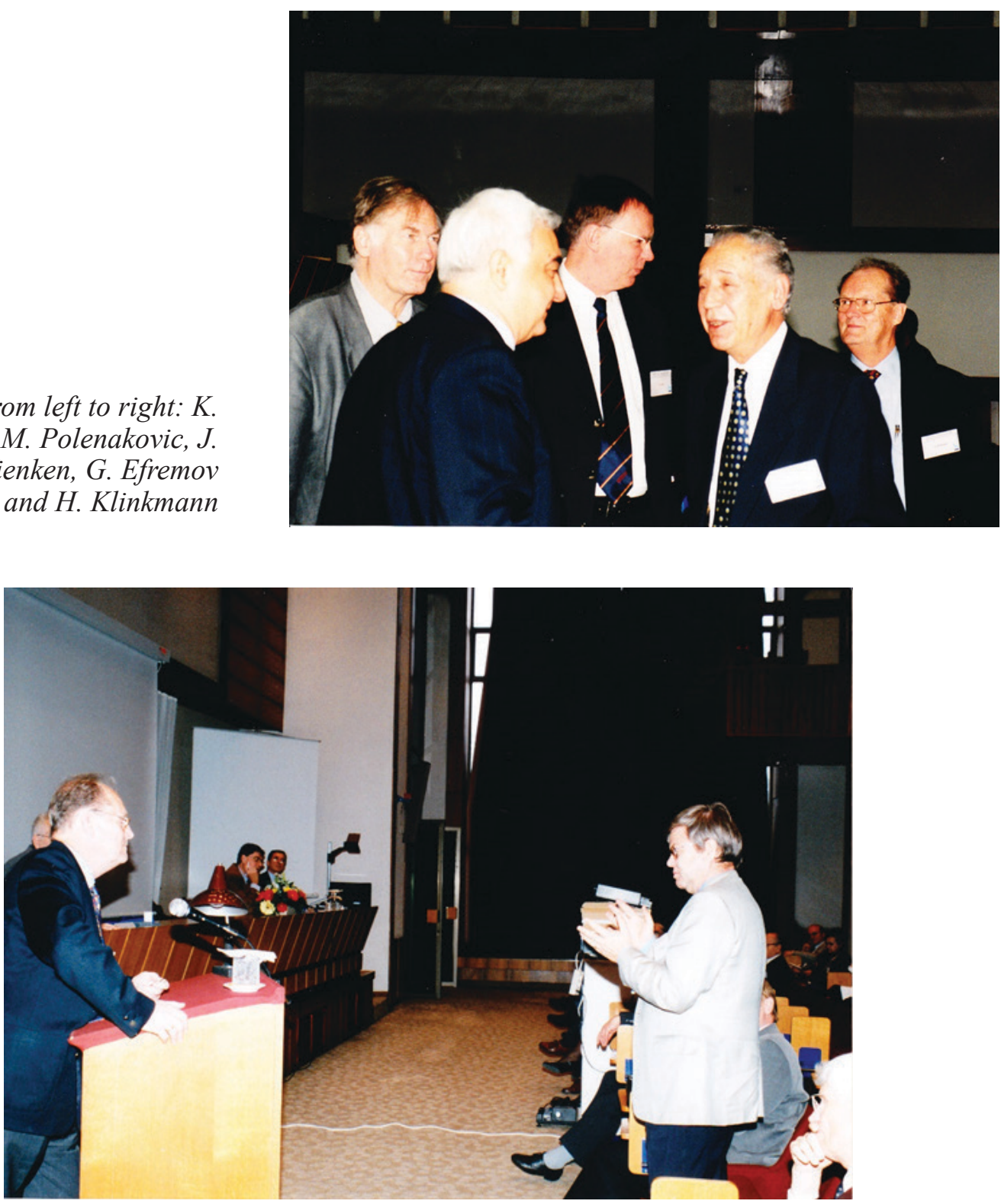

Fig. 7. H. Klinkmann and D. Falkenhagen 


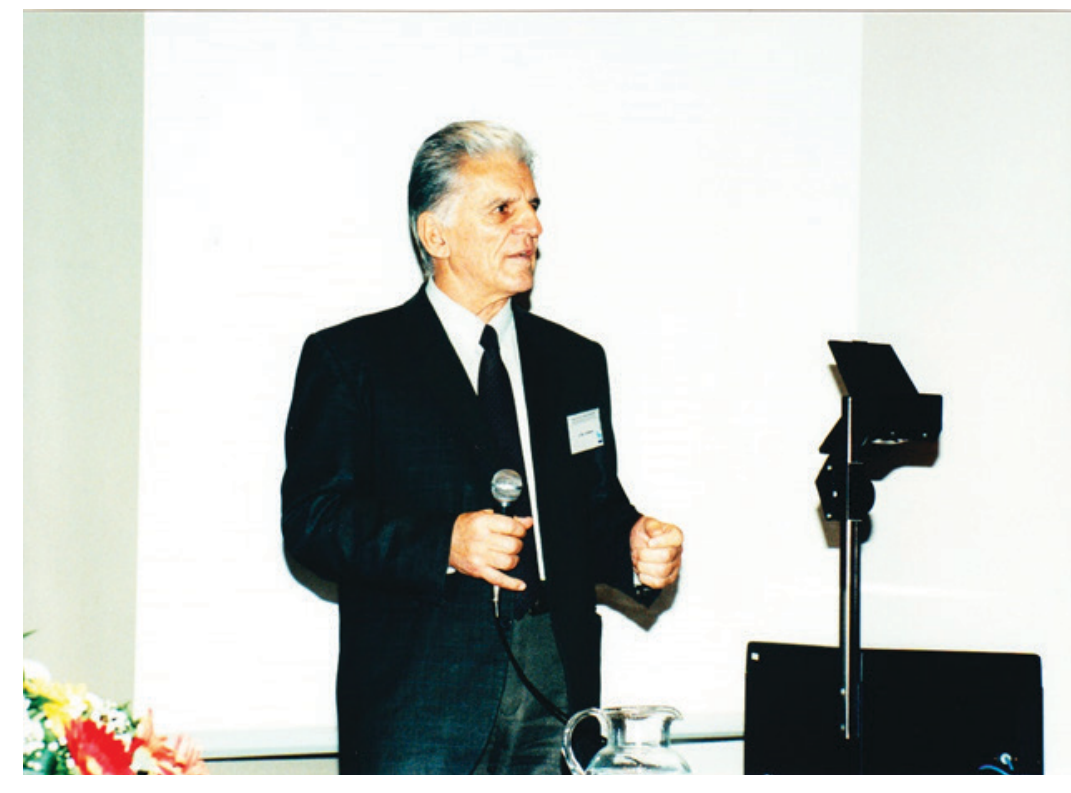

Fig. 8. J. Pop-Jordanov

Fig. 9. From left to right: $G$. Rakhorst, M. Polenakovic and D. Falkenhagen
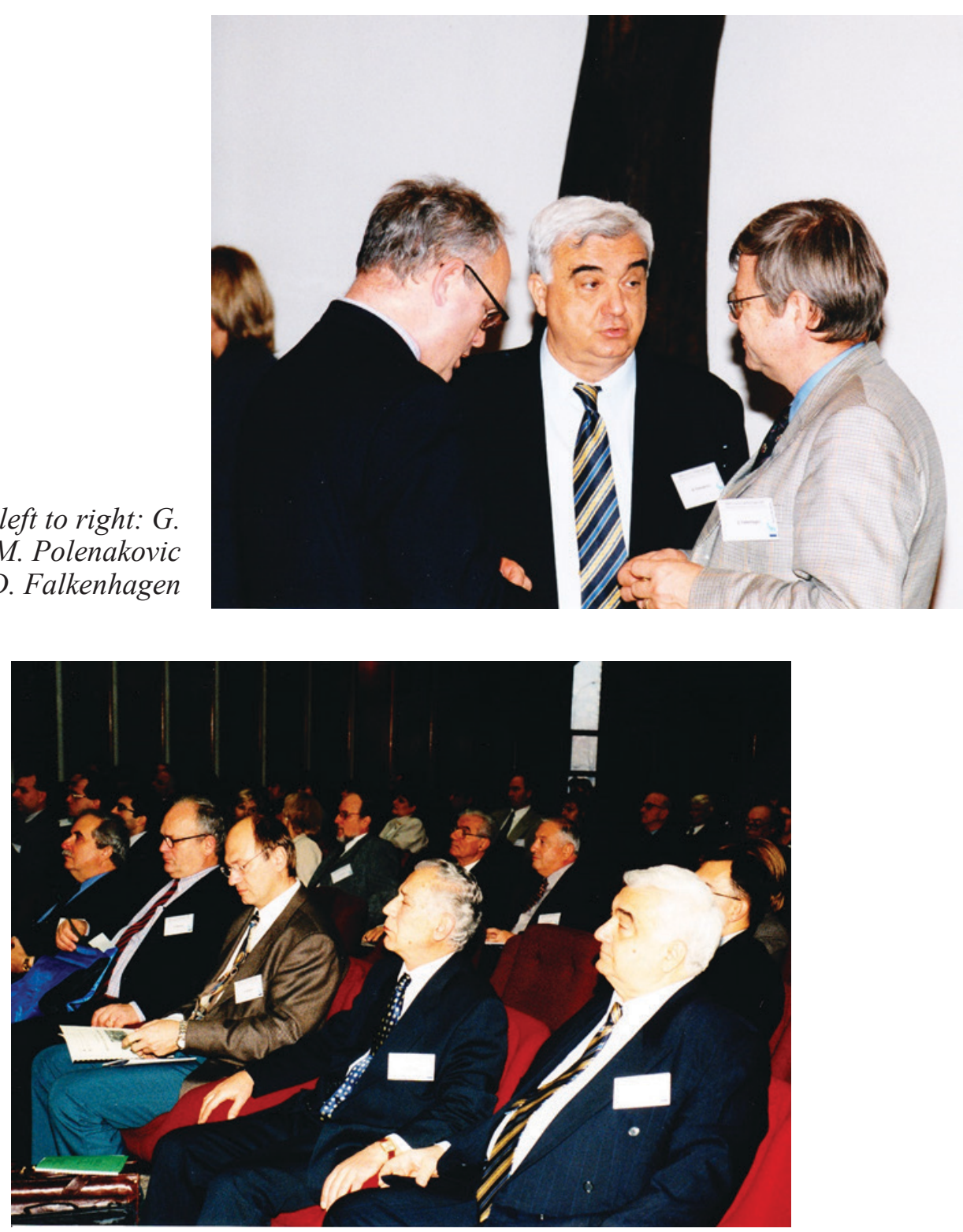

Fig. 10. Participants in the Symposium 
The presentations provoked a fruitful discussion and it was concluded that work should be done on the development of artificial organs for each human parenchymal organ. Artificial organs need to be widely available to any patient who needs them.

The quality of the presented papers, the achievements in the research and the new ideas for the artificial organs led to the conclusion that the presented presentations should be printed in the International Journal of Artificial Organs of the European Society for Artificial Organs (ESAO) as a special issue.

We, from R. Macedonia, were especially honored that ESAO dedicates a special issue to the International Journal of Artificial Organs: "Artificial

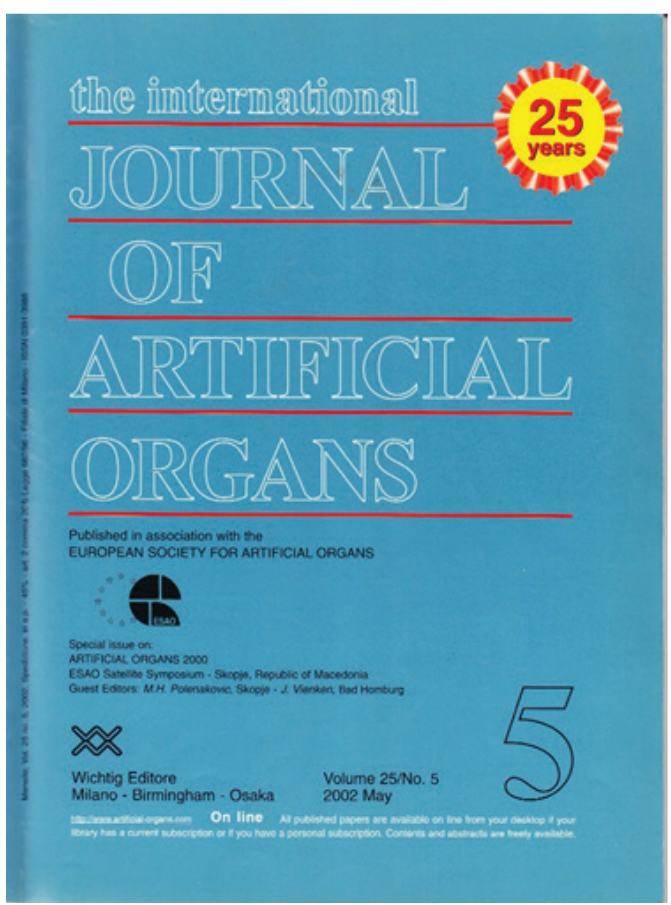

Organs 2000 ESAO Satellite Symposium - Skopje, R. Macedonia".

The special issue of the journal came out in May 2002; No. 5; Vol. 25.

We enclose the foreword to the Artificial Organs 2000 ESAO Satellite Symposium entitled "25 Years of active research on artificial organs at the Department of Nephrology at the Skopje University of Ss. Cyril and Methodius" by M. H. Polenakovic and J. Vienken, published in the International Journal of Artificial Organs, Vol. 25, No. 5, 2002, p. 345 (5).

In addition, we enclose the abstracts of the printed papers:

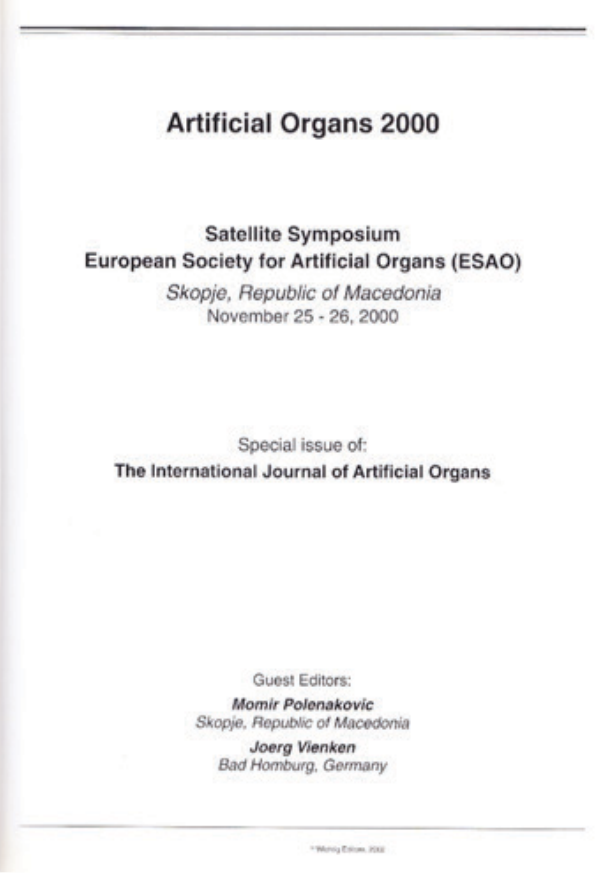




\section{Foreword}

Research on Artificial Organs has a long and enduring history in Macedonia, mainly at the University of Ss. Cyril and Methodius in the Macedonian Capital of Skopje. Here, intensive investigations on Artificial Organs have been performed in cooperation with the Department of Nephrology. A series of excellent publications in peer-reviewed journals have appeared in recent years confirming the high standard of research in this Balkan country.

In November 2000, the Department of Nephrology of Skopje University, St. Cyril and Methodius, celebrated its $25^{\text {th }}$ anniversary. The European Society for Artificial Organs (ESAO) took this as an opportunity to organize the Symposium "Artificial Organs 2000". This symposium took place in Skopje on November 25. 26, 2000 at the Macedonian Academy of Sciences and Arts and attracted many renowned speakers and participants from all over Europe. Not surprisingly, it proved an interesting fact to the public: a close relationship exists between the University of Skopje and other European Universities, as well as an intense and reciprocal interest in cultivating collaboration between these Institutions. This symposium has further demonstrated that open and friendly cooperation is possible between European and Macedonian scientists despite the turbulent political situation of the Balkan Peninsula.

The main topics of this symposium were: Blood-purification techniques, Artificial Kidney, Metabolic- and Cardiac-Assist Systems as well as Biomaterials to be used for Artificial Organs. Selected papers of this symposium are collected in this special number of the International Journal of Artificial Organs. We believe that this issue represents a highly interesting overview of current aspects of scientific research in the field of Artificial Organs. We hope that the papers published here will stimulate further scientific cooperation and foster mutual understanding between the Balkan and other European countries.

Twenty-five years of research on Artificial Organs at the University of Skopje deserve warm congratulations for such a successful program in such difficult political times. Twenty-five years of scientific success encourage us to hope that many years of scientific exchange and efficient cooperation lay ahead of us.

Momir Polenakovic Skopje, Republic of Macedonia

Joerg Vienken

Bad Homburg, Germany 


$\overline{\text { Artificial Kidney, Blood Purification and Vascular Access }}$

\section{Vascular access}

R. VANHOLDER

Nophrology Unt, Departmont of interral Mediche, Univerasty Hospital, Gent - Belgium

INTRODUCTION

Without adequate vascular access, $t$ is impossible to er elficiont hemodialysis to pationts with end-stage tecroased delivery of dialyser blood flow as well as of reductions of effective dialysis time. The logical consequence is a fall of total clearance. By its influence on dialysis adequacy. vascular access has a final pcess possibuties havo in be faced with a life-threatoning condition During the last decade, nophrologists have been confronted
moro and more frequently with such a potentialty fatal milo and more frequently with such a potentially fatal
svolution. Hence, there is no debate that vascular rocess is the Achilles heel of todays hemodialysis. fowever, it is also the Cinderella, because progress in search and development have been much slower and ess adequate than in any other field of dialysis care.
Tho ideal accoss should consistently allow tho teal accoss should consistently allow for slood flow to maximize dialysis delivery and this ndefinitely long. Complications such as thrombosis. fifoction and hemorthage should be absent. Such deal accoss does howevor not exist as of today. In a study from the United States, access-related
roblems were held responsible for $48 \%$ cospitalization (11). Hence, the quality of $48 \%$ ccoss is not only a modical issue, but aleo a sochconomic matter. The nephrologic community the eeds reliable research data that should make The to improve access quality. Sosibiilities, togenther with thesenty available access research and development. are summarized in Tate The purpose of the present paper is to discuss thes cossibitities one by one and to point out the potent

(a)

One of the obvious problems with vasounar acoess is angong process is stant the first access is created, an access possibilities, it the pationt survivos long pough. A carelul application of all possibilities will quality of lifo longer than it access systems are constructod and moniloced carelessty The Cimino-Brescia fistula

In 1966, Cimino, Brescia, Appell and co-workers first then, shun's composed of artificie me reviat that bridged the arterial and venous vascular beds. had been used as access systems. Because of the foreign frequent corplications The arterio and infection were on the other hand, consisted of andogenous endothelialized vessel material. Therefore, infoction and thrombosis became substantially less the lowererant. Ideally, the AV-fistula is constructed in in the arm, up to the elbow and above. These sites can bo used as an alternative option if yascular quality in the lower arm is insulficient. In some situations, such as even the approach of preteterongs this higher location is even the approach of preferenoe, because of the The creation of the Cimino-Brescia fistula needs the presence of adequate and patent arteries and veins. This implies a timely referral of the patient to the nephrologist. When a patient has progrossive renal

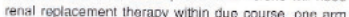
should be preserved tor the future creation of a vascular access system. By preterence, the nondominant arm is chosen for this approach, if the quality

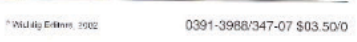

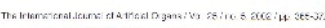
Artificial Kidney, Blood Purification and Vascular Access

Various clinical approaches to minimise complications in peritoneal dialysis

B. STEGMAYR

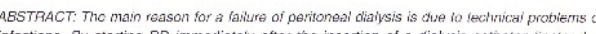
infections. By starting PD immediately atter the insortion of a clialysis catheter finstead of

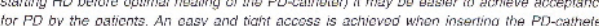

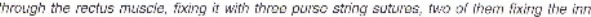
cuil between the peritonioal mombrano and tho innor roctus fascia. Thereby eariy and late leakege whl be rare and good drainage is normally achicved besides a low risk for exif sitc

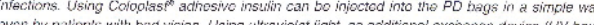

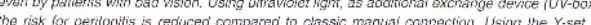
ouo-bag systers the risk for peritonitits is further iovered. Malitunction by distocation of the intrapertioneal part of the catheters car othen bo corrccitod withour surgery using a bent striet $A$ controlled study showed that antibiotic propinyiactics could significantly reduce the risk for

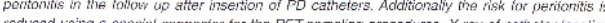

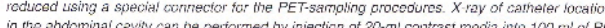

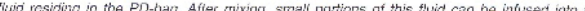

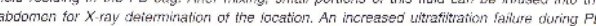
may bo duc to use of bela-biocker rnedication. After ceasing this modication recovery masy occur. Avoiding pots in the room used tor PD-exchange may lower the risk for pertibridis further

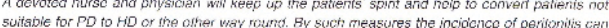
be reducod to 1 in 40 treatrent months or less. (Int J Artif Organs 2002: 25: 365-72)

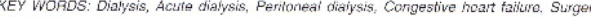

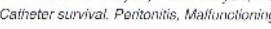

Peritoneal dialysis (PD) corresponds to about $20 \%$ of over $90 \%$ (4) and UK, about $45 \%$ while it is very limito (onic dialysis (1) and only exclusively is a part of in Japan (abour 6\%) (1).

erations there is also fent as HD in adecuacy and long letrri survival (2). hesitation to initiate PD due to the risks for

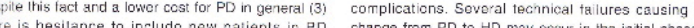
grams. This difference vaces from contre to cerlte betore commencing chrons oxiaur in the intial phas nd tha inclusicns are most orominont in $A$. . Mexico. obstruction, pe foration, bleedirg, post-oocrative

Artificial Kidney, Blood Purification and Vascular Access

Approach to vascular access for hemodialysis: experiences from the Republic of Macedonia

A. ONCEVSKI, P. DEJANOV, V. GERASIMOVSKA, M.H. POLENAKOVIC

Department of Nephrology, Clinical Center; Ss.Cyril and Methodius - University. Skooje - Reppubic of Macedonia

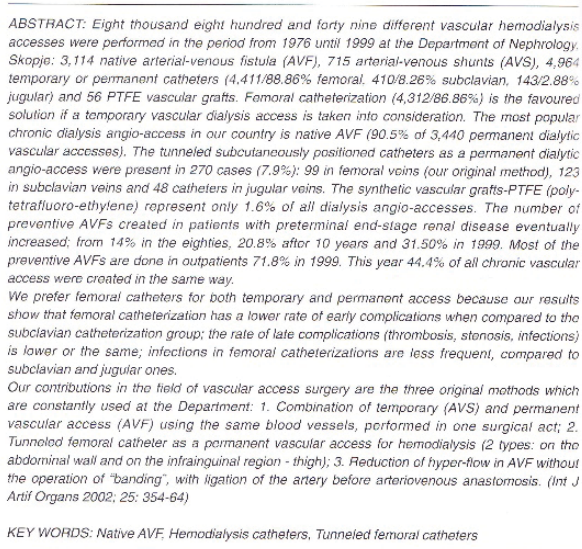

INTRODUCTION

Only patients (pls) with APF were dialyzed \{1\}.

The first hemodialysis (HD) in the Republic of of Nephrology in Skopje starled with 12 pts in 1971 Macedonia was performed in 1959 on a patient with Now, in 2000, in the Republic of Macedonia wo have 18

0391-3988:354-011 905 500

Artificial Kidney, Blood Purification and Vascular Access

\section{Vitamin $\mathrm{E}$ as an antioxidant agent in CAPD patients}

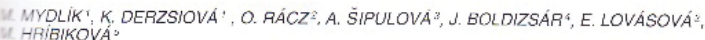

Nephrological Cliric, Uriversity Hospital, Kosice - Slovak Ropublic

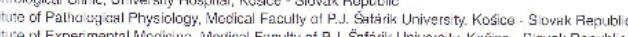

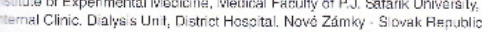

epartment ol Clinical Biochemistry, Disaricici Hospi:al, Noyè Zamky - Slovak Republic

ABSTRACT: Oxidative stress, increasod fipid peroxidation and decroased activily of antoxidan systems may contribute to the accolerated develoornent of athorosclerosis in chronic rend

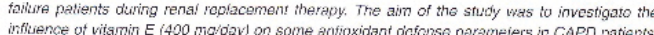

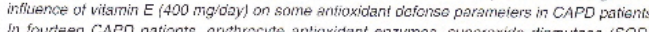
In fouteen CAPD pationts, orythrochte antioxidant enzymos, superoxide dismutase (SOD) gituidhione poroxidaso (GPX) and catalase (CAT), the concentration of plasm

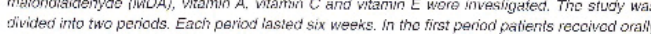

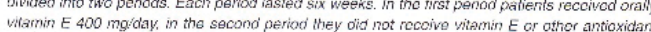
drugs. Each paramotor vas deternioed at the beginning of the study and at the ond of each period. Six CAPD patients were trated by erythropo:atin (EPO) and received orally pyidoxine $20 \mathrm{mg}$ olay and the others withoul EPO treatment received pyridoxine $5 \mathrm{mg} / \mathrm{day}$. Six-week ireatment by vitamin $E$ ( $400 \mathrm{mg} / \mathrm{day})$ ied to the significant increase of servm vitamin $E$ (fror $33.6 \pm 9.0$ to $49.3 \pm 55.5$ umolh) and io the significant decrease of MDA (from $2.62 \pm 0.5$ : $2.36 \pm 0.4$ wmolli, The maen values of erythrocyte enzymos vere in or under the fowor margi oi nomal range and vere not influenced by vitamin E in CAPD patients antioxidant

$K E Y$ WORDS: Vitamin $E_{1}$ Antioxidant defense parameters, CAPD palients

\section{NTRODUCTION}

Atherosclerosis is a leading cause of death in patients with end-stage renal cisease including thos Tong-torm renal replacement therapy $(1,2)$ xidizability of low-density lipoproteins $i L \mathrm{DL}$ ) hos been reposed as an explanation for accelerated ardioyasculur complications in chronic renal failure oatients undergoing dialysis i 3 .

Alpha-locopherol (vitamin E) is a liposcluble vitami placod on cell membranes and its main function is to protect polyunsaturated tatty ac ds against axidative aggreass on, hius preseving is in:egrty (4). Vtamin E the most abundant antloxicant present, and also the only sign a cant antoxidant in LOL. Tis a chinin-breakin antoxidant, apving peroxy trod adicals and it is a

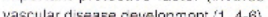
However there are discropanc (ave's in uremis pationts on hes about serum CAPD

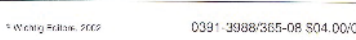

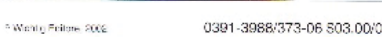


Art ilicial Kidiney, Blood Purification and Vascular Access

Filtration fluid for hemodialysis treatment

V RONONOV: G MASE', L STEFANDIS: H. MELZER', H. MUNW

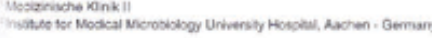

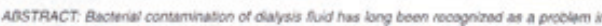

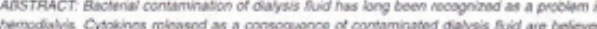

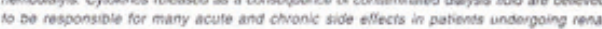

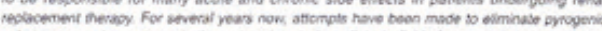

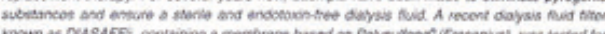

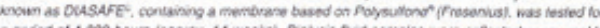

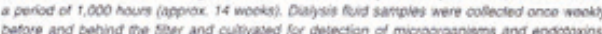

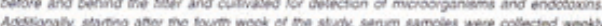

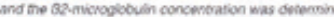

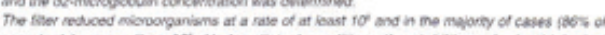

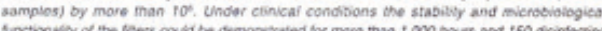

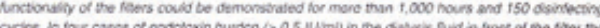

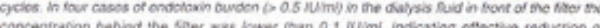

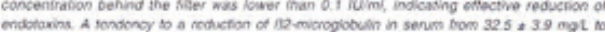

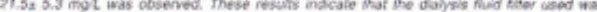

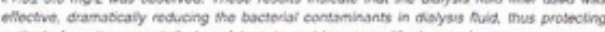

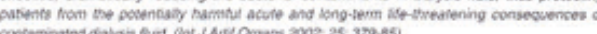

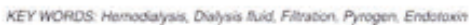

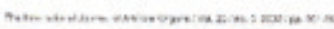
(ketificial Kidney, Bicod Purmeation and Vaseular Aceoss

\section{Extracorporeal treatment strategy in acute renal failure}

4. JARES

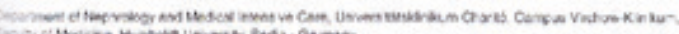

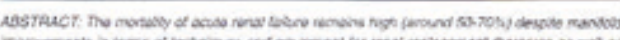

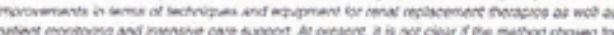

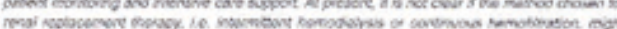

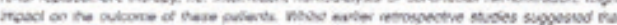

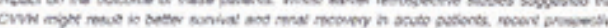

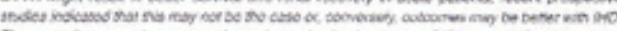

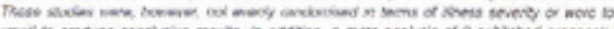

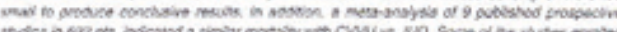

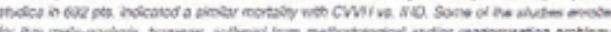

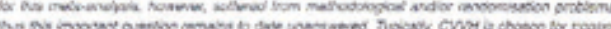

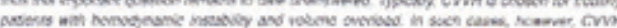

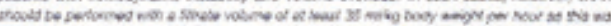

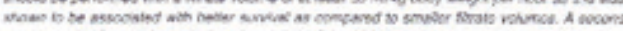

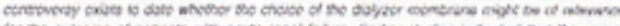

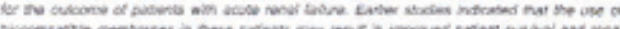

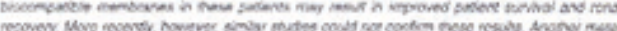

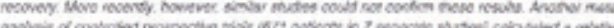

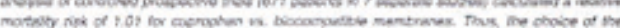

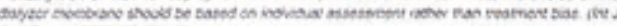
and opvos ans as me

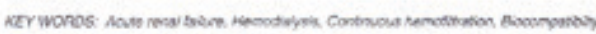

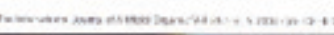

Westoolic and Cardias Assist Technobogy and Other Scien:ito Rewhs

Ischemic dilatative cardiomyopathy and aneurysms of the left ventricular cavity:

transplantation vs alternative surgery

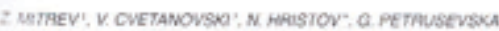

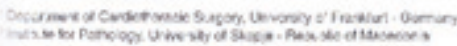

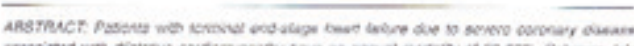

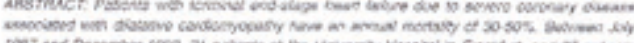

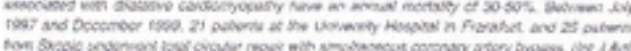

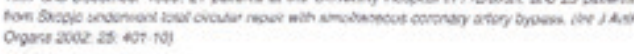

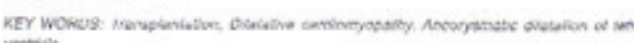
uretsit:

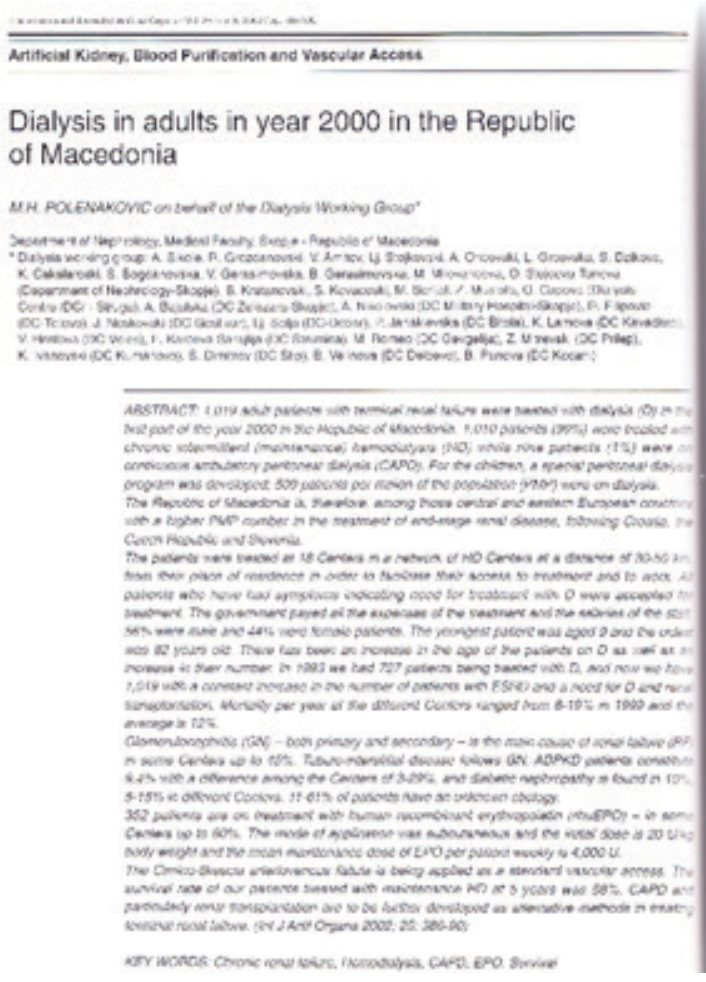

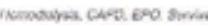

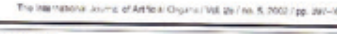

Priorities in renal replacement programs

BONOMINI

ABSTAACT: The vanious anternative programs in renal replacement therapy have preciso

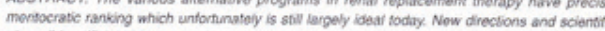

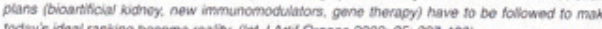

KEY WORDS: Rena roplacement therapy

Wetabolic and Cardiac Assist Technology and Other Scientilic Realms

Sodium and body fluid homeostasis in profiling nemodialysis treatment

STEFAMOIS', S. STLLER', V KKONOMOV', H. MAN"

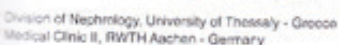

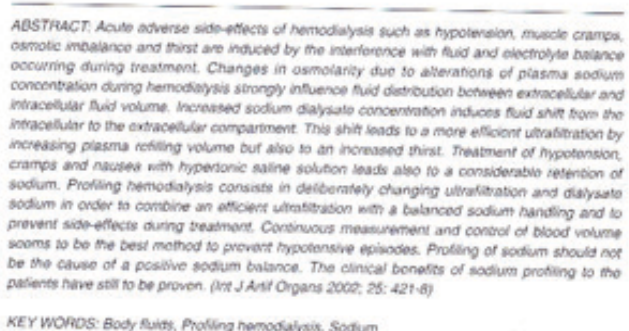

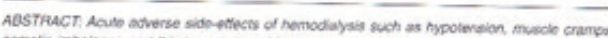

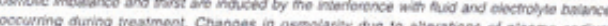

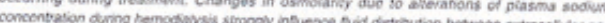

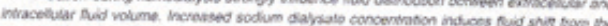

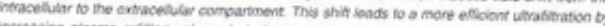

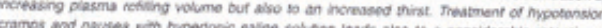

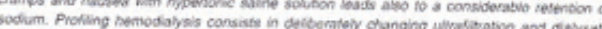

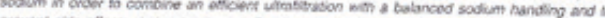

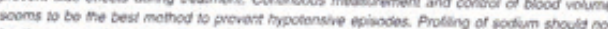

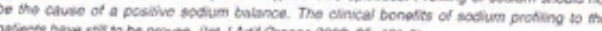

KEY WOROS: Body Eliss, Pralling nemodalysis, Sodun 


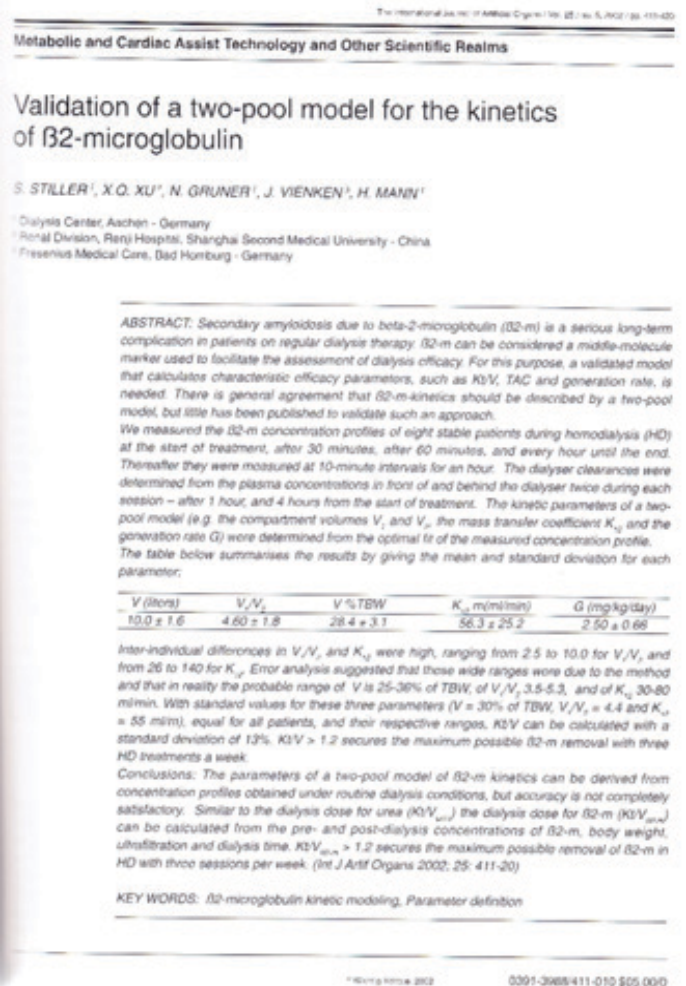

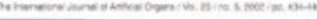

Biomaterials and their Application

Biodegradable polymeric matrices for bioartificial implants

E. PIșaw

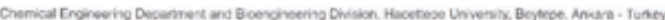

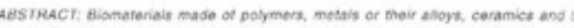

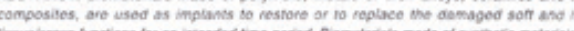

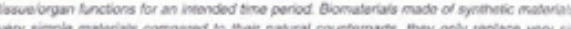

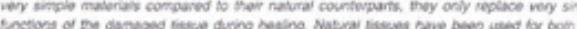

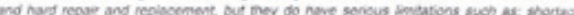

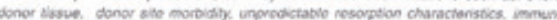

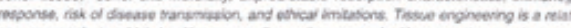

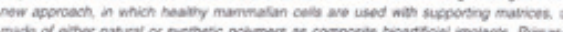

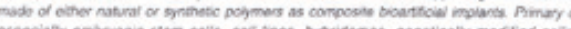

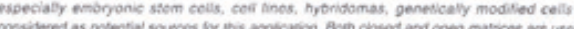

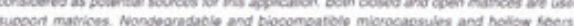

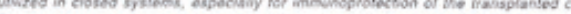

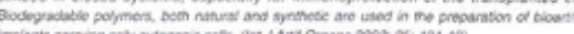

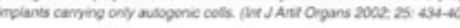

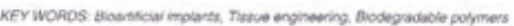

Biomateriats and their Application

Dialysis membranes today

s $x$ Bowerr

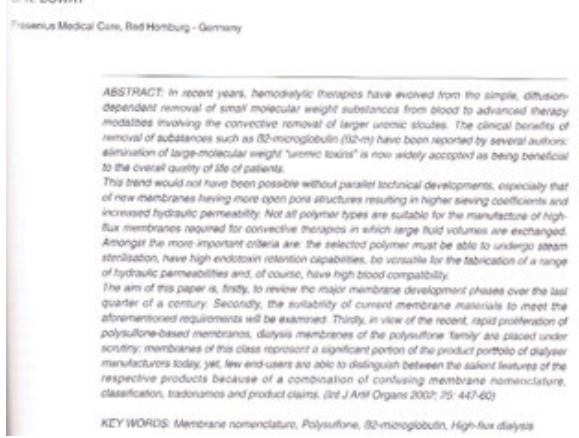

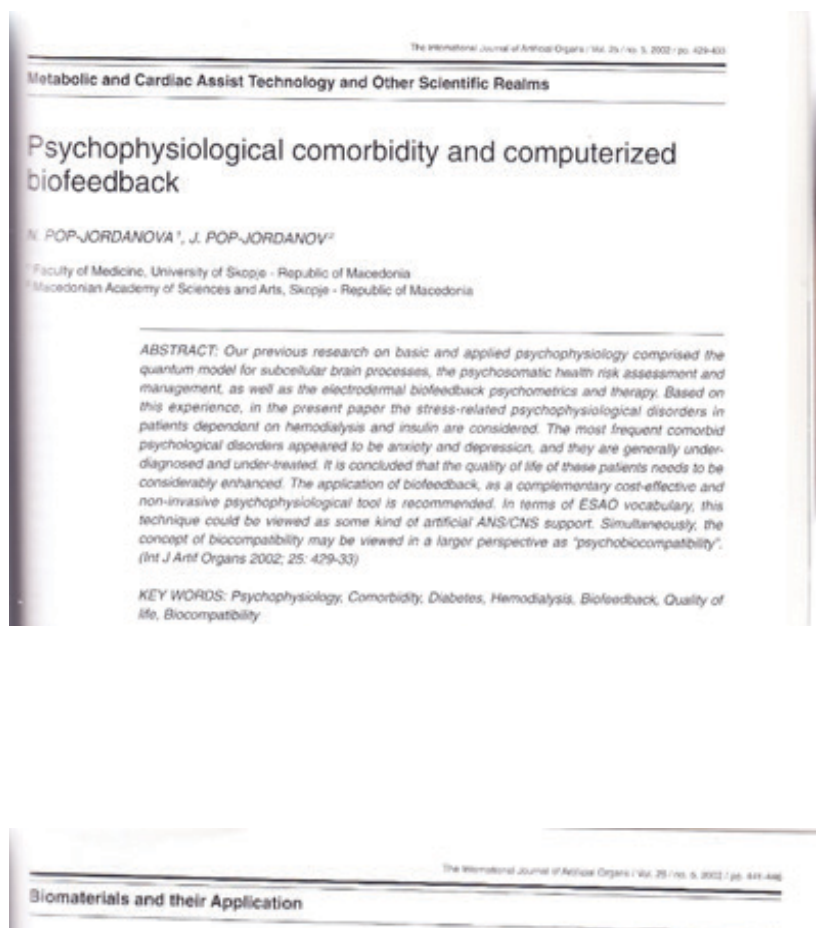

Testing protein permeability of dialysis membranes using SDS-PAGE

H. MANN, H. MELZER, A. AL-BMSHIR, XO XU, S. STILLER

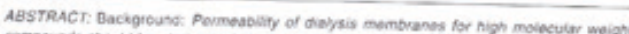

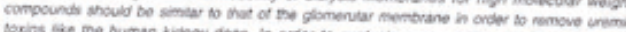

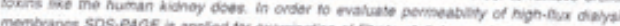
wot diflewent membranes Uothod: SOS.PACE ariers

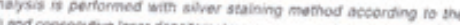

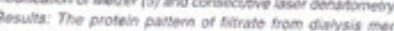

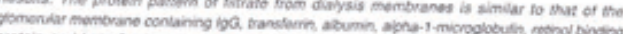

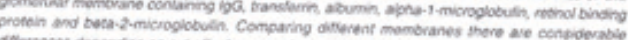

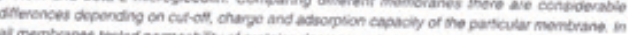

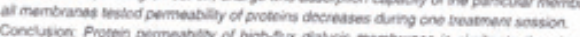

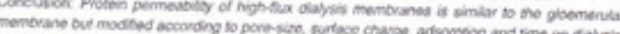

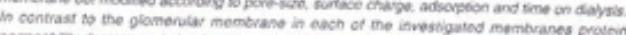

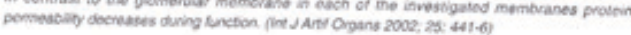

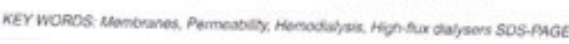

Biomaterials and their Application

Heparin-coated versus uncoated Palmaz-Schatz stent in native coronary circulation. A randomized study with blind angioscopic assessment

S. KEDEV: G GUAGLIUM" , O. VALSECHI?, M. TESPH"

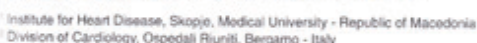

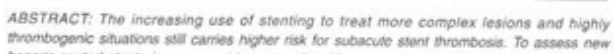

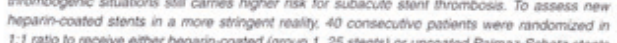

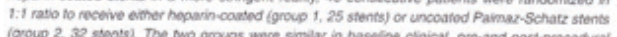

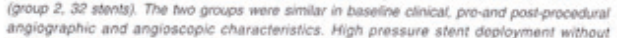
angiographic and angioscopic characteristics. High pressure stent deployment without

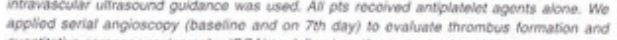

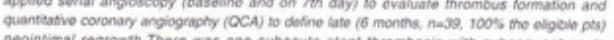

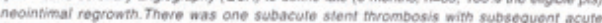

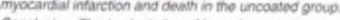

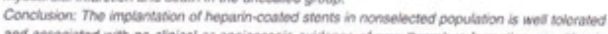

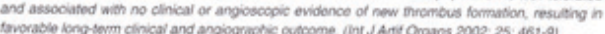

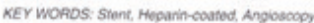




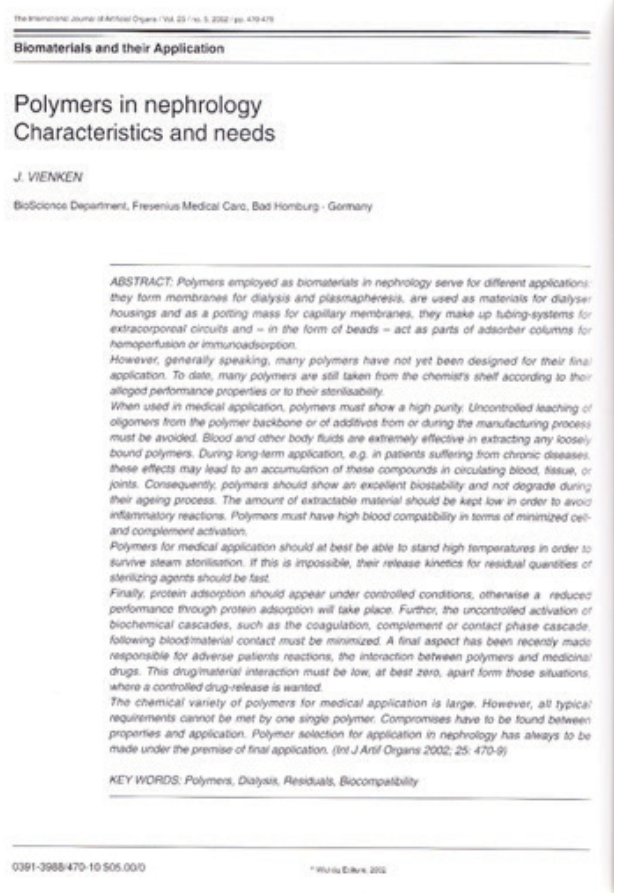

Twenty years after the Artificial Organs 2000 ESAO Satellite Symposium at the clinics of the Medical Faculty of the University of "Ss. Cyril and Methodius" in Skopje, all types of dialysis and plasmapheresis are performed, kidney transplantations are performed from a living donor and from cadaver. Dialysis is provided in R. Macedonia to patients who need it in 25 dialysis centers across the country with 1619 patients in 2019 (Table 1).

\begin{tabular}{|c|c|c|}
\hline No. & Dialysis Center & Number of patients \\
\hline & Department of Nephrology, Medical Faculty, Skopje & 33 \\
\hline & $\begin{array}{l}\text { Hemodialysis Center, General Hospital "8. September", } \\
\text { Skopje }\end{array}$ & 62 \\
\hline & $\begin{array}{l}\text { Special hospital for nephrology and hemodialysis } \\
\text { DIAMED - Gjorche Petrov, Skopje }\end{array}$ & 119 \\
\hline & DIAMED - Zelezara, Skopje & 132 \\
\hline & DIAMED - Vizbegovo, Skopje & 215 \\
\hline & DIAMED - Delchevo & 32 \\
\hline & DIAMED - Gevgelija & 36 \\
\hline & DIAMED - Shtip & 43 \\
\hline & DIAMED - Kochani & 50 \\
\hline & DIAMED - Strumica & 80 \\
\hline & DIAMED - Kumanovo & 84 \\
\hline & DIAMED - Kriva Palanka & 28 \\
\hline & Nephrology Center, Struga & 120 \\
\hline & Peritoneal dialysis & 17 \\
\hline & Home dialysis & 1 \\
\hline & Sistina Nephroplus, Tetovo & 154 \\
\hline & Sistina Nephroplus, Gostivar & 75 \\
\hline & Sistina Nephroplus, Debar & 21 \\
\hline & Sistina Nephroplus, Struga & 15 \\
\hline & Sistina Nephroplus, Ohrid & 40 \\
\hline & Sistina Nephroplus, Kichevo & 32 \\
\hline & Sistina Nephroplus, Bitola & 69 \\
\hline & Sistina Nephroplus, Prilep & 69 \\
\hline & Sistina Nephroplus, Kavadarci & 45 \\
\hline & Sistina Nephroplus, Veles & 47 \\
\hline & TOTAL & 1619 \\
\hline
\end{tabular}


Table 1 presents the hemodialysis centers in N. Macedonia with the patients they treat. The data for 2019 are obtained from D. Gjorgjiev, President of the Association of Renal Patients "Nefron", Skopje.

In 2020, the first heart transplant was performed at the Medical Faculty in Skopje. Complex heart surgeries as well as on other parenchymal organs are performed in clinics and hospitals.

We try to follow the development and application of artificial organs according to the most modern achievements and guidelines that exist in the world.

Acknowledgement to Goce Aleksoski for the technical assistance.

The paper is part of the project "History of Nephrology in North Macedonia", funded by the Macedonian Academy of Sciences and Arts

\section{REFERENCES}

1. Willem J Kolff MD, PhD. Biography and Interview www.achievement.org American Academy of Achievement

2. T. Stojcevski. Overview of the history of hematology in the world and in Macedonia. Skopje p. 185-186; 2010

3. Arsov D. Hrisoho D., Guceva B., Guceva S. Polenakovic M. Treatment of patients with acute renal failure with special reference to our experience with hemodialysis. Mac. med. review 26: 3-14, 1971

4. Polenakovic M. Department of Nephrology at the Medical Faculty, Ss. Cyril and Methodius University, Skopje - Creating nephrology protection for the citizens of the Republic of Macedonia. Contributions (Prilozi). Sec. Med. Sci., XXXIV1, 2013

5. M. H. Polenakovic, J. Vienken. 25 years of active research on artificial organs at the Department of Nephrology of Skopje, University Ss. Cyril and Methodius (Foreword). The International Journal of Artificial Organs, Vol. 25, No. 5, p. 345, 2002 


\section{Резиме}

\section{ВЕШТАЧКИ ОРГАНИ 2000}

Сателитски симпозиум по повод 25-годишнината на Клиниката за нефрологија на Универзитетот „Св. Кирил и Методиј“, Скопје, Р. Македонија, 25 и 26 ноември 2000 година

\section{Момир Х. Поленаковиќ}

Македонска академија на науките и уметностите, Скопје, РС Македонија

Сателитскиот симпозиум на Европското друштво за вештачки органи „Вештачки органи 2000“ беше организиран од Македонското здружение за нефрологија, дијализа, трансплантација и вештачки органи (МЗНДТВО) и Македонската академија на науките и уметностите (МАНУ) на 25 и 26 ноември 2000 година, по повод 25 -годишнината на Клиниката за нефрологија на Универзитетот „Св. Кирил и Методиј“, Скопје, Р Македонија. Главни теми на овој симпозиум беа: Техники за прочистување на крвта, вештачки бубрези, метаболички и кардиолошки системи, како и биоматеријали што се користат за вештачки органи.

Своите трудови на Симпозиумот ги презентираа: H. Klinkmann (Glasgow, United Kingdom), D. Falkenhagen (Krems, Austria), U. Baurmeister (Wuppertal, Germany), V. Bonomini, S. Stefoni (Bologna, Italy), R. Vanholder (Ghent, Belgium), S. Stiller (Aachen, Germany), H. Mann, H. Melzer (Aachen, Germany), J. Pop-Jordanov, N. Pop-Jordanova (Skopje, R. Macedonia), B. Stegmayr (Umea, Sweden), M. Mydlik, K. Derzisova, O. Racz, A. Sipulova, J. Boldizsar, E. Lovasova, M. Hribikova (Kosice, Slovak Republic), A. Jörres (Berlin, Germany), M. Polenakovic (Skopje, R. Macedonia), J. Vienken (Bad Homburg, Germany), S. Bowry (Bad Homburg, Germany), E. Piskin (Ankara, Turkey), J. Klinkmann, W. Schimmelpfennig, H. Lantow, W. Rigger. (Teterow, Germany), A. Sikole (Skopje, R. Macedonia), A. Oncevski, P. Dejanov, V. Gerasimovska, M. Polenakovic (Skopje, R. Macedonia), J. Wojcicki (Warsaw, Poland), K. Affeld (Berlin, Germany), G. Rakhorst et al. (Groningen, The Netherlands), Z. Mitrev (Skopje, R. Macedonia), S. Kedev, G. Guagliumi, O. Valsecchi, M. Tespili (Skopje, R. Macedonia, Bergamo, Italy).

Презентациите предизвикаа плодна дискусија и беше заклучено дека тие треба да бидат објавени. Трудовите се објавени во the International Journal of Artificial Organs of the European Society for Artificial Organs (ESAO) како специјален број за „Artificial Organs 2000 ESAO Satellite Symposium - Skopje, R. Macedonia“, Guest Editors: M. H. Polenakovic, Skopje and J. Vienken, Bad Homburg; Vol. 25, No. 5, 2002.

Клучни зборови: вештачки бубрег, прочистување на крв, васкуларен пристап, технологија за срцево помагање, инженерство на ткива, психофизиологија 